\title{
STATE LAW OF CONTRACT FORMATION IN THE SHADOW OF THE FEDERAL ARBITRATION ACT
}

\author{
TRACI L. JONES

\section{INTRODUCTION}

The Federal Arbitration Act (FAA) ${ }^{1}$ was passed in 1925 to ensure the enforceability of arbitration clauses and codify the procedures through which such clauses would be enforced. ${ }^{2}$ Ever since its passage, state courts and legislatures have attempted to define the role that remains for state arbitration law in light of the Act's sweeping provisions. ${ }^{3}$ The dimensions of this role were sharply narrowed in a trilogy of opinions by the U.S. Supreme Court. ${ }^{4}$ These opinions broadened the scope of the FAA, perhaps beyond that which Congress originally intended, ${ }^{5}$ and established the FAA as a body of substantive federal law that preempts all contradictory state arbitration law. ${ }^{6}$

This broad interpretation of the FAA has been a source of controversy within the Supreme Court, among various federal courts, and between federal and state courts. The case which defined the preemptory effect of the FAA, Southland Corp. $v$. Keating, ${ }^{7}$ revealed disagreement ainong the Justices over the FAA's preemptory force. Justices O'Connor and Rehnquist strongly dissented, arguing that the majority opinion "utterly fail[ed] to

1. Ch. 213,43 Stat. 883 (codified at 9 U.S.C. $\$ \S 1-16,201-08$ (1994)).

2. See Southland Corp. v. Keating, 465 U.S. 1, 10-12 (1984).

3. See IAN R. MACNEIL, AMERICAN ARBITRATION LAW: ReFormation, NATIONALIZATION, AND INTERNATIONALIZATION 127-30 (1992) (discussing state cases applying the FAA after the Act's passage); see also Voters Said Yes to Amendments, But Court Will Have the Last Word, OMAHA WORLD-HERALD, May 19, 1996, at 14B (discussing Nebraska's struggle with arbitration laws).

4. See Perry v. Thomas, 482 U.S. 483, 489-91 (1987); Southland, 465 U.S. at 10-12; Moses H. Cone Mem'l Hosp. v. Mercury Constr. Corp., 460 U.S. 1, 24 (1983).

5. See Allied-Bruce Terminix Cos. v. Dobson, 115 S. Ct. 834, 845-50 (1995) (Thomas, J., dissenting); Perry, 482 U.S. at 493 (Stevens, J., dissenting); Southland, 465 U.S. at 25 (O'Connor, J., dissenting).

6. See Southland, 465 U.S. at $15-16$. Preemption occurs by virtue of Congress' power under the Commerce Clause. See id. at 11-16.

7. 465 U.S. 1 (1984). 
recognize the clear congressional intent underlying the FAA."8 Congress' intent, according to the dissenting Justices, was "to require federal, not state, courts to respect arbitration agreements." Although Justice O'Connor has not dissented in more recent opinions considering the preemptory effect of the FAA, ${ }^{10}$ she has stated that she remains convinced that "Congress never intended the Federal Arbitration Act to apply in state courts." 11 Justices Scalia and Thoinas have also vigorously dissented in opinions considering the scope of Southland, calling the Southland decision simply "wrong."12 Justice Scalia has expressed his opinion that "Southland clearly misconstrued the Federal Arbitration Act"13 and has declared his readiness "to join four other Justices in overruling it."14 Thus, the controversy over the FAA and the Southland decision persists in the Supreme Court.

The effect of Southland and its progeny on state law has also opened a rift between soine state and federal courts. ${ }^{15}$ This rift was most clearly illustrated by Circuit Judge Bruce $\mathrm{H}$. Selya, writing for the First Circuit. ${ }^{16}$ In Securities Industry Association $v$. Connolly, Judge Selya bemoaned state resistance to the FAA and argued that the Act was "therapy for the ailment of the crowded docket.... [But as] might be expected ... the patient, and others in interest, often resist the treatment."17

One such "patient," Justice Terry N. Trieweiler of the Supreme Court of Montana, responded in an opinion that "[such] arrogance not only reflects an intellectual detachment from reality,

8. Id. at 22-23 (O'Connor, J., dissenting).

9. Id. at 23 .

10. See Doctor's Assocs., Inc. v. Casarotto, 116 S. Ct. 1652 (1996).

11. Allied-Bruce Terminix Cos. v. Dobson, 115 S. Ct. 834, 844 (1995) (O'Connor, J., concurring). Justice $O^{\prime}$ Connor has stated she will acquiesce in majority opinions in deference to stare decisis until there is a "'special justification' to overrule Southland." Id. (citing Arizona v. Rumsey, 467 U.S. 203, 212 (1984)).

12. Dobson, 115 S. Ct. at 845 (Thomas, J., dissenting).

13. Id. (Scalia, J., dissenting).

14. Id.

15. The rift has also opened between some state courts and legislatures. For example, Nebraska courts have long held arbitration provisions relating to future disputes unenforceable under the Nebraska Constitution. See Nebraska v. Nebraska Ass'n of Pub. Employees, 477 N.W.2d 577, 582 (Neb. 1991). This sentiment was shared neither by the Nebraska legislature nor by the state's citizens; this past summer the citizens of Nebraska passed a constitutional amendinent authorizing arbitration in all circumstances. See Volers Said Yes to Amendments, But Court Will Have the Last Word, supra note 3, at 14B.

16. See Securities Indus. Ass'n v. Connolly, 883 F.2d 1114 (1st Cir. 1989).

17. Id. at 1116. 
but a self-serving disregard for the purposes for which courts exist." In the same opinion, Justice Trieweiler and three other state supreme court justices upheld Montana's arbitration law, resisting "treatinent." 19 The U.S. Supreme Court later reversed the Montana Court without addressing any of Justice Trieweiler's concerns. ${ }^{20}$ In "symbolic protest," Justice Trieweiler refused to sign the Supreme Court's remand order. ${ }^{21}$

Despite the sweep of the FAA, states do have a role in the creation of arbitration law. In fact, this role should satisfy Justice Trieweiler. This Note explores, in higlt of Southland and the more recent Doctor's Associates, Inc. v. Casarotto, ${ }^{22}$ the role that remains for state arbitration law. ${ }^{23}$ In particular, this Note argues that state law of contract formation can be used to protect individuals from unfair arbitration agreements without running afoul of the FAA.

Part I of this Note outlines the history of the FAA and analyzes the cases that have expanded the Act's scope. Part II evaluates the spht among circuits over the role of state contract law under the FAA. Part II argues that state, not federal, law should govern formation questions and concludes that state courts and legislatures can regulate arbitration provisions-in a manner consistent with the FAA and Southland-by revising their laws of contract formation. Part III analyzes Justice Trieweiler's contro-

18. Casarotto v. Lombardi, 886 P.2d 931, 940 (Mont. 1994) (Trieweiler, J., specially concurring), vacated and remanded 115 S. Ct. 2552 (1995), reaffd and reinstated 901 P.2d 596 (Mont. 1995), rev'd 116 S. Ct. 1652 (1996). Justice Trieweiler added that Judge Selya's opinion illustrated "an all too frequent preoccupation on the part of federal judges with their own case load and a total lack of consideration for the rights of individuals." Id.

19. See id. at 939.

20. See Doctor's Assocs., Inc. v. Casarotto, 116 S. Ct. 1652, 1656-57 (1996) (holding that Montana's law directly conflicts with the FAA because it conditions the enforceability of arbitration agreements on compliance with a special notice requirement not applicable to contracts generally).

21. See Richard C. Reuben, Western Showdown: Two Montana Judges Buck the U.S. Supreme Court, A.B.A. J., Oct. 1996, at 16 (quoting Erwin Cheinerinsky).

22. 116 S. Ct. 1652 (1996).

23. This Note will not examine the soundness of Southland and its progeny. There is a rich body of literature on that subject. See, e.g., Linda R. Hirshman, The Second Arbitration Trilogy: The Federalization of Arbitration Law, 71 VA. L. REV. 1305 (1985); Janet M. Grossnickle, Note, Allied-Bruce Terminix Co. v. Dobson: How the Federal Arbitration Act Will Keep Consumers and Corporations Out of the Courtroom, 36 B.C. L. REV. 769 (1995); David P. Pierce, Comment, The Federal Arbitration Act: Conflicting Interpretations of Its Scope, 61 U. CN. L. REV. 623 (1992). 
versial opinion in Casarotto v. Lombardi ${ }^{24}$ and the Supreme Court's response. Part IV then examines how the question in Casarotto might be restated as one of contract formation, such that the result in Casarotto can be seen as one consistent with Southland.

\section{HISTORY OF THE FEDERAL ARBITRATION ACT}

Arbitration is a process that allows parties to "voluntarily refer their disputes to an impartial third person, an arbitrator, selected by thein for a decision based on the evidence and arguments to be presented before the arbitration tribunal."25 Unlike judicially enforced dispute resolution, arbitration is voluntary and can be imposed only when all parties agree to its use. ${ }^{26}$ Many contracting parties stipulate that disputes arising from their contracts will be referred to an arbitrator because arbitration allows parties to settle their disputes in an "inexpensive and speedy" fashion and to pick the presiding judge. ${ }^{27}$

Despite the consensual nature and apparent ease of arbitration, courts historically have been reluctant to enforce arbitration agreements. ${ }^{28}$ Lackluster enforcement of arbitration agreements has been attributed to the jealous guard courts keep over their jurisdiction ${ }^{29}$ and to soine courts' reluctance to specifically enforce arbitration agreements. ${ }^{30}$ Because of this weak enforcement, indi-

24. 886 P.2d 931 (Mont. 1994), vacated and remanded, 115 S. Ct. 2552 (1995); reaff'd and reinstated 901 P.2d 596 (Mont. 1995), rev'd, 116 S. Ct. 1652 (1996).

25. MARTIN DOMKE, 1 DOMKE ON COMMERCIAL ARBITRATION § 1:01 (1996).

26. See id.

27. Id. (quoting Gates v. Arizona Brewing Co., 95 P.2d 49, 50 (Ariz. 1939)).

28. See DOMKE, supra note 25, \& 3.01; see also Southland Corp. v. Keating, 465 U.S. 1, 13-14 (1984) (reviewing the legislative history behind the FAA and noting the unwillingness of state courts to enforce arbitration agreements). For an early history of arbitration, see Hirshman, supra note 23, at 1309-14.

29. See H.R. REP. No. 96-68, at 1-2 (1924). The House Report specified that the need for the Federal Arbitration Act

arises from .... the jealousy of the English courts for their own jurisdiction .... This jealousy survived for so long a period that the principle became firmly embedded in the English common law and was adopted with it by the American courts. The courts have felt that the precedent was too strongly fixed to be overtumed without legislative enactment .... Id.

30. See Hearing on S. 4213 and S. 4214 Before a Subcomm. of the Senate Comm. on the Judiciary, 67th Cong. 6 (1923) (remarks of Sen. Walsh); see also S.M. Wolff Co. v. Tulkoff, 174 N.E.2d 478, 480 (N.Y. 1961) ("At common law, 'Arbitration agreements . . . meant very little' because they were not subject to specific enforcement." (quoting In re 
viduals who explicitly desired and contracted for arbitration were left unsure if the arbitration provisions agreed to in their contracts would be enforced.

In response to this lackluster enforcement $t^{31}$ and the need for contractual certainty, ${ }^{32}$ Congress passed the FAA in $1925 .^{33}$ The Act mandated enforcement of arbitration clauses contained in all contracts involving maritime transactions or interstate commerce. $^{34}$ The Act also contained procedural provisions that einpowered courts ${ }^{35}$ to stay proceedings until the close of arbitration $^{36}$ or to compel arbitration. ${ }^{37}$ With these provisions, Congress

Feuer Transp., Inc., 65 N.E.2d 178, 180 (N.Y. 1946))).

31. See Allied-Bruce Terminix Cos. v. Dobson, 115 S. Ct. 834, 838 (1995) ("[T]he basic purpose of the Federal Arbitration Act is to overcome courts' refusals to enforce agreements to arbitrate."); see also Robert Lawrence Co. v. Devonshire Fabrics, Inc., 271 F.2d 402, 406-07 (2d Cir. 1959) (holding that "[f]or a considerable time prior to the passage of the Arbitration Act in 1925 the Congress had come to the conclusion that an effort should be made ... to remove the hostility of the judiciary and make the benefits of arbitration generally available to the business world.").

32. See Metro Indus. Painting Corp. v. Terminal Constr. Co., 287 F.2d 382, 387 (2d Cir. 1961) (Lumbard, C.J., concurring) ("[T]he purpose of the [FAA] was to assure those who desired arbitration and whose contracts related to interstate commerce that their expectations would not be undermined by federal judges, or . . . by state courts or legislatures.").

33. Arbitration Act of Feb. 12, 1925, ch. 213, 43 Stat. 883 (codified at 9 U.S.C. §§ 1-16, 201-208 (1994)).

34. See 9 U.S.C. \& 2 . This section provides:

A written provision in any maritime transaction or a contract evidencing a transaction involving commerce to settle by arbitration a controversy thereafter arising out of such contract or transaction, or the refusal to perform the whole or any part thereof, or an agreement in writing to submit to arbitration an existing controversy arising out of such a contract, transaction, or refusal, shall be valid, irrevocable, and enforceable, save upon such grounds as exist at law or in equity for the revocation of any contract.

Id.

35. The Supreme Court has yet to decide whether $\S \S 3$ and 4 of the FAA, the procedural provisions, apply to state courts. See Volt Info. Sciences, Inc. v. Board of Trustees of Leland Stanford Junior Univ., 489 U.S. 468, 477 n.6 (1989) ("While we have held that the FAA's 'substantive' provisions- $\$ \$ 1$ and 2-are applicable in state as well as federal court ... we have never held that $\S \S 3$ and 4 , which by their terms appear to apply only to proceedings in federal court ... are nonetheless applicable in state court."); cf. Moses H. Cone Mem'l Hosp. v. Mercury Constr. Corp., 460 U.S. 1, 26 (1983) (stating in dictum that "state courts, as much as federal courts, are obliged to grant stays of litigation under $\S 3$ of the Arbitration Act"). The question of whether $\S 3$ and $\S 4$ are applicable to state courts is outside of the scope of this Note. For a detailed discussion of that topic, see Jon R. Schumacher, Note, The Reach of the Federal Arbitration Act: Implications on State Procedural Law, 70 N.D. L. REV. 459 (1994).

36. See 9 U.S.C. $\$ 3$.

37. See 9 U.S.C. $\$ 4$. 
intended to create "a national policy favoring arbitration and [to withdraw] the power of the states to require a judicial forum for the resolution of claims which the contracting parties agreed to resolve by arbitration." $" 38$

This intended policy of the FAA was thwarted for inany years, in part, by the perceived limited scope of the Act $^{39}$ The FAA did not specify whether it was procedural or substantive in nature, or if its parts were severable. ${ }^{40}$ Most commentators believed the FAA liad force only in federal courts, ${ }^{41}$ and in the decades after its passage, only federal courts deferred to the FAA. ${ }^{42}$ Moreover, for twenty years following its passage, no reported state case even considered applying the FAA in a state proceeding. ${ }^{43}$

The Suprene Court's decision in Erie Railroad Co. $v$. Tompkins ${ }^{44}$ forced courts to consider the precise contours of the FAA $^{45}$-whether the Act's requirements were procedural (and therefore apphicable in federal diversity cases), substantive (and inapphicable in diversity cases), or something altogether different. ${ }^{46}$ This consideration of the FAA in light of Erie's holding did not begin, however, until nearly thirty years after the deci-

38. Southland Corp. v. Keating, 465 U.S. 1, 10 (1984).

39. See MACNEIL, supra note 3, 122-24.

40. See Moses H. Cone Mem'l Hosp., 460 U.S. at 24; see also Schumacher, supra note 35, at 476-77 (discussing whether $\$ \$ 3$ and 4 of the FAA are binding on state courts and the impact of severing $\$ \S 1$ and 2 of the FAA from $\$ \S 3$ and 4).

41. See Henry C. Strickland, The Federal Arbitration Act's Interstate Commerce Requirement: What's Left for State Arbitration Law? 21 HoFSTRA L. REV. 385, 391 (1992) (citing Harry Baum \& Leon Pressman, The Enforcement of Commercial Arbitration Agreements in the Federal Courts, 8 N.Y.U. L.Q. REV. 238, 428, 430-31, 459-60 (1930-31)) ("Courts and commentators concluded, almost unanimously, that the Act applied in all federal cases . . . . Few if any commentators, neanwhile, thought that state courts were obligated to apply the Act."); see also MACNEIL, supra note 3, at 122-24 (discussing commentaries published immediately following the passage of the FAA).

42. See MACNEIL, supra note 3, at 131-33; Strickland, supra note 41, at 391.

43. See MACNEIL, supra note 3, at 127-28 (citing French v. Petrinovic, 54 N.Y.S.2d 179 (N.Y. App. Div. 1945), as the first decision in which a state court considered apply a ing the FAA). In the "thirty-four years after its enactment, the [FAA] had yielded a grand total of only five reported cases in which efforts had been made to have it applied in state courts." Id. at 128 .

44. 304 U.S. 64 (1938).

45. For a discussion of the theoretical tensions between Erie and the FAA as it was construed in 1938, see Strickland, supra note 41, at 391-95.

46. See Erie, 304 U.S. at 78 (holding generally that there is no federal common law and that federal courts must apply substantive state law in diversity cases). 
sion. ${ }^{47}$ The first significant post-Erie announcement of the FAA's scope occurred in 1967, with the Supreme Court's decision in Prima Paint Corp. v. Flood \& Conklin Manufacturing Co ${ }^{48}$ In Prima Paint, the Court found that the FAA was an exercise of Congress' power under the Commerce Clause; ${ }^{49}$ the Act therefore created a body of substantive federal rights, not mere federal procedure..$^{50}$ As a result, the Court held that the FAA was applicable in all cases involving interstate commerce. ${ }^{51}$

It was yet another twenty years, however, before the Court defined the relationship between this federal law and state law. ${ }^{52}$ In Moses H. Cone Memorial Hospital v. Mercury Construction Corp. ${ }^{53}$ the Court developed the general principle that ascribed to Congress the intent to have the FAA "[create] a body of federal substantive law." ${ }^{354}$ Furthermore, the Court held that the FAA

mandate[d] enforcement of all covered arbitration agreements; Congress [could] hardly have meant that an agreement to arbitrate [could] be enforced against a party who attempts to litigate an arbitrable dispute in federal court, but not against one who sues on the same dispute in state court. ${ }^{55}$

Thus, the FAA appeared to apply in both state and federal courts. This general principle was delineated one year later in Southland Corporation v. Keating. ${ }^{56}$ In Southland, the Supreme Court held that $\S 2$ of the FAA-the mandatory enforcement provision-was applicable in both state and federal courts. ${ }^{57}$ Fur-

47. See MACNEIL, supra note 3 , at 136.

48. 388 U.S. 395 (1967). Ian Macneil argues that the Supreme Court's opinion in Bernhardt v. Polygraphic Co. of America, 350 U.S. 198 (1956), set the stage for Prima Paint, but nevertheless concedes that "few knew what had hit them when Prima Paint was decided." See MACNEIL, supra note 3, at 138. Thus, it is accurate to characterize Prima Paint as the first consideration of the FAA in light of Erie. The gap in time between Erie and Prima Paint (or Bernhardt for that matter) can only be explained by the "undiscussed and unstated assumption that state law governed" arbitration issues generally. Id. at 138-39.

49. See Prima Paint, 388 U.S. at 404-05.

50. See Moses H. Cone Mem'l Hosp. v. Mercury Constr. Co., 460 U.S. 1, 24-25 (1983).

51. See Prima Paint, 388 U.S. at 405.

52. See MACNEII, supra note 3, at 134-48.

53. 460 U.S. 1.

54. Id. at 25 n.32.

55. Id. at 27 n.34.

56. 465 U.S. 1 (1984).

57. See id. at 12 . 
ther, state statutes preventing the enforcement of arbitration agreements were invalid under the Supremacy Clause. ${ }^{58}$ The Court reasoned that, by passing the FAA, "Congress intended to foreclose state legislative attempts to undercut the enforceability of arbitration agreements." 59 The preemptive effect of the FAA has been affirmed in subsequent Supreme Court decisions. ${ }^{60}$

The Southland Court did identify two limits on the enforceability of arbitration clauses: "[the clauses] must be part of a written maritime contract or a contract 'evidencing a transaction involving commerce' and such clauses may be revoked upon such 'grounds as exist at law or in equity for the revocation of any contract." ${ }^{\prime 61}$ Following Southland, litigants who wanted to resist arbitration under the FAA urged courts to give effect to the first limit. ${ }^{62}$ They argued that $\S 2$ of the FAA specified that the Act applies only to arbitration provisions "in any maritime transaction or a contract evidencing a transaction involving commerce."63 They then argued that their particular contract fell outside of the scope of the FAA because the contract did not involve interstate commerce. However, the Supreme Court rejected this argument

58. See id. at 16. The conflicting state law in Southland was the California Franchise Investment Law. CAL. CORP. CODE $\S 31,000$ et seq. (West 1977). One section of that statute provided that "[a]ny condition, stipulation or provision purporting to bind any person acquiring any franchise to waive compliance with any provision of this law or any rule or order hereunder is void." CAL. CORP. CODE $\S 31,512$. Because the statute had the effect of preventing arbitration of claims brought under the franchise law, it conflicted with the FAA. See Southland, 465 U.S. at 16.

59. Id.

60. See Allied-Bruce Terminix Cos. v. Dobson, 115 S. Ct. 834, 837-38 (1995) (holding that the FAA preempts a state law making written, pre-dispute arbitration agreements invalid and unenforceable); Perry v. Thomas, 482 U.S. 483, 491 (1987) (invalidating a section of the California Labor Code which effectively foreclosed arbitration by requiring litigants to seek a judicial forum for resolving wage disputes).

There are some indications, however, that even a slight change in the makeup of the Supreme Court could lead the Court to overrule Southland and its progeny. See supra notes 7-14 and accompanying text.

61. Southland, 465 U.S. at 10-11 (citations omitted).

62. See, e.g., Dobson, 115 S. Ct. at 843 (rejecting the argument that the termite-control contract at issue involved interstate commerce); Laclieney v. Profitkey Int'l, Inc., 818 F. Supp. 922, 923-24 (E.D. Va. 1993) (finding a personal service contract performed in Virginia involved interstate commerce); Burke County Pub. Schs. Bd. of Educ. v. Shaver Partnership, 279 S.E.2d 816, 819 (N.C. 1981) (holding an architectural contract involved interstate commerce); see also Strickland, supra note 41, at 386, 400-406 (arguing that determining the FAA's applicability has increased in importance and examining the scope of the FAA's applicability).

63. 9 U.S.C. \& 2 (1994) (emphasis added). 
and the idea that the commerce requirement provided any real limit on the scope of the FAA in Allied-Bruce Terminix Cos. $v$. Dobson. ${ }^{64}$

Dobson involved the arbitration provision of a "Termite Protection Plan" contract between an Alabama homeowner and the local Terminix franchise ("Terminix"). ${ }^{65}$ When the homeownerplaintiff discovered his house was still infested with termites after Terminix had ostensibly exterminated them, he sued Terminix. ${ }^{66}$ Terminix moved to stay the proceedings pending arbitration. ${ }^{67}$ The Supreme Court, considering an appeal from the Alabama Supreme Court's decision to refuse the stay, held that the Terminix contract evidenced a "transaction involving commerce," and therefore was governed by the FAA. ${ }^{68}$

In so holding, the Court found that the phrase "involving commerce" as used in the FAA was the functional equivalent of the phrase "affecting commerce"; therefore, the FAA's language signalled "congressional intent to exercise its Commerce Clause powers to the full." As a result, not "only persons or activities within the flow of interstate commerce" fell within the FAA's ambit, ${ }^{70}$ but all persons and activities subject to the commerce power generally. The Court justified this broad interpretation of $\S 2$ as consistent with the Act's basic purpose:

[A] narrower interpretation [would not be] consistent with the Act's purpose, for ... such an interpretation would create a new, unfamiliar, test lying soinewhere in a no-inan's land between "in commerce" and "affecting commerce," thereby unnecessarily complicating the law and breeding litigation from a statute tliat seeks to avoid it. ${ }^{71}$

Thus, the Court effectively eliminated the first and most obvious limitation on the FAA's preemptive effect.

64. $115 \mathrm{~S}$. Ct. at $839-40$.

65. See id. at 837.

66. See id.

67. See id.

68. See id. at 843.

69. Id. at 839.

70. Id. (quoting United States v. American Bldg. Maintenance Indus., 422 U.S. 271, 276 (1975)).

71. Id. at 840 . 


\section{State LAW of Contract Formation Under the FAA}

The FAA's far-reaching scope and its apparent lack of exceptions have led some commentators to argue that arbitration law has been completely "federalized" and state arbitration law completely eviscerated. ${ }^{72}$ Nevertheless, state law has been held to govern a few limited questions of arbitration agreements. For example, parties can 'contract out' of the FAA's mandates by specifying that state arbitration rules will govern their arbitration agreement. ${ }^{73}$ Such "contracting out" is justified because if parties agree to "abide by state rules of arbitration," application of the FAA "would be quite inimical to the FAA's primary purpose of ensuring that private agreements to arbitrate are enforced according to their terms." While "contracting out" of the FAA allows private parties to avoid the FAA's mandates, it does not solve the concern of states. That is, the alternative of "contracting-out" is available only in contract situations between imdividuals, the state laving no right of participation in nor control over the contract's mandates. Yet the state has a legitimate interest in protecting its citizens and, absent the use of "contracting out" provisions, a weak party may still be subject to contracts of adhesion and may be forced into a different, unwanted forum. "Contracting out" of the FAA does not "de-federalize" arbitration law in any meaningful way, smce it does not explicitly provide states an active voice in the creation of arbitration law.

That voice may, lowever, be found in the single remaining textual exception to the FAA-the second limitation referred to in the Southland opinion. ${ }^{75}$ This exception provides that state arbitration law may supersede the FAA in certain instances, nainely "upon such grounds as exist at law or in equity for the revocation of any contract." Arbitration clauses can be evaluated by state courts in two instances: 1 ) to determine whether a valid arbitration clause was formed by the parties (i.e., questions of contract formation); and 2) to determine what issues the parties agreed to arbitrate (i.e., the scope of the agreed-upon arbitration). When eval-

72. See Hirshman, supra note 23 , at $1305-08$.

73. See Volt Info. Sciences, Inc. v. Board of Trustees of Leland Stanford Junior Univ., 489 U.S. 468, 478-79 (1989); see also supra notes 26-27 and accompanying text.

74. Id. at 479 .

75. See 465 U.S. at 10-11 (1984).

76. 9 U.S.C. $\S 2$ (1994). 
uating questions of formation, judges may consider "attacks on the making of the agreement"-arguments that no contract was formed-as well as arguments for revoking the contract, such as laches, waiver and unconscionability. ${ }^{77}$

\section{A. Different Views of the Role of State Contract Law}

At first, it appears unclear if it is state or federal law that should govern questions of whether an agreement to arbitrate has been formed. Federal courts do not agree on this issue. Some circuits have held that questions of validity, enforceability and revocability of an arbitration agreement are governed by federal, not state, law. For example, in Genesco, Inc. v. T. Kakiuchi \& Co. ${ }^{78}$ the Second Circuit bound the parties to an arbitration agreement that was printed on the back of a sales confirmation form because, under general federal contract principles, "there was an objective agreement with respect to the entire contract."79 This rationale was offered despite contrary state law that would have invalidated the arbitration provision as a material alteration of the contract. ${ }^{80}$ Justifying this apphication of federal law, the Second Circuit argued that the FAA was a large body of

national substantive law governing questions of the validity and the enforceability of arbitration agreements under its coverage .... Hence whether [a party] is bound by the arbitration

77. See Hirshman, supra note 23 , at 1336 n.183; see also Perry v. Thomas, 482 U.S. 483, 492 n.9 (1987) (stating in dictum that the phrase "save upon such grounds" implicates issues of an agreement's validity, as well as its revocability and enforceability); Note, Erie, Bernhardt, and Section 2 of the United States Arbitration Act: A Farrago of Rights, Remedies, and a Right to a Remedy, 69 YALE L.J. 847, 860 n.81 (1960) (interpreting the term "revocation" in $\$ 2$ to mean "avoidance").

78. 815 F.2d 840 (2d Cir. 1987).

79. Id. at 846 (citing $\mathrm{N} \& \mathrm{D}$ Fashions, Inc. v. DHJ Indus., Inc., 548 F.2d 722, 727 (8th Cir. 1976)). Cf. First Options of Chicago, Inc. v. Kaplan, 115 S. Ct. 1920, 1923-26 (1995) (applying state law of contract formation without invoking the $\S 2$ exception); Supak \& Sons Mfg. Co. v. Pervel Indus., Inc., 593 F.2d 135, 137 (4th Cir. 1979) (using the "any contract" language rather than the exception language of $\S 2$ for determining the issue of whether a contract to arbitrate was formed, thereby classifying the issue as determinable according to state law).

80. See, e.g., Coastal Indus., Inc. v. Automatic Steam Prods. Corp. 654 F.2d 375, 378-79 (5th Cir. 1981) (analyzing the same question as in Genesco but applying New York state law and reaching the opposite result). Under New York law, "an arbitration clause constitutes a per se material alteration of a contract" for purposes of N.Y. U.C.C. $\S 2-207$. Id. at 379 (citing Fairfield-Noble Corp. v. Pressman-Gutman Co., 475 F. Supp. 899, 902 (S.D.N.Y. 1979)). 
clause of [a contract] is determined under federal law, which comprises generally accepted principles of contract law. ${ }^{81}$

\section{This view has been adopted by other courts in more recent cas- es. $^{82}$}

Other circuits treat the question of whether an arbitration clause is part of a contract as an issue of state law. For example, the Fourth Circuit has held that whether an arbitration clause is part of a contract, as required by $\S 2$ of the FAA, is a question of "state law on the general principles governing forination of the contract itself." 83 This finding-that state law of contract formation has a role under the FAA - has been subsequently affirmed by the Fourth Circuit ${ }^{84}$ and adopted by other circuits. ${ }^{85}$

81. Genesco, 815 F.2d at 845 (emphasis added, citations omitted); see also Par-Knit Mills, Inc. v. Stockbridge Fabrics Co., 636 F.2d 51, 54-55 (3d Cir. 1980) (evaluating a question of contract formation generally within the framework of the FAA).

82. See, e.g., Degaetano v. Smith Bamey, Inc., 1996 U.S. Dist. LEXIS 1140, at *9.*10 (S.D.N.Y. 1996) (holding that courts must apply federal substantive law to determine arbitrability); In re Milliken \& Co., 1992 U.S. Dist. LEXIS 11195, at $* 19$ (S.D.N.Y. 1992) (" $[T]$ he Second Circuit has clearly stated that whether parties are bound by an arbitration clause under the FAA is determined by federal law, not state law."); see also Neal v. Hardee's Food Sys. Inc., 918 F.2d 34, 37 \& n.5 (5th Cir. 1990) (holding that federal law governed the question of whether separate agreements should be construed together to determine if an arbitration agreement had been formed); Mago v. Shearson Lehinan Hutton Inc., 956 F.2d 932, 934 (9th Cir. 1992) (holding that federal, not state law, governed the question of whether an arbitration agreement was an adhesion contract); Cohen v. Wedbush, Noble, Cooke, Inc., 841 F.2d 282, 285 (9th Cir. 1988) (holding that the FAA is a single unified body of federal law that governs all defenses against the validity of an arbitration agreenent).

83. Supak \& Sons Mfg. Co. v. Pervel Indus., 593 F.2d 135, 137 (4th Cir. 1979) (citing Duplan Corp. v. W. B. Davis Hosiery Mills, Inc., 442 F. Supp. 86 (S.D.N.Y. 1977)).

84. See, e.g., Roddick v. Marsh \& McLeunan, Inc., 1993 U.S. App. LEXIS 142, at $* 4$ (4th Cir. 1993); W. M. Schlosser Co. v. School Bd., 980 F.2d 253, 258-59 (4th Cir. 1992) (holding that federal courts cannot order parties to arbitrate if there is no valid arbitration agreement, and it is state law that governs whether a valid arbitration agreement has been formed); see also Saturn Distrib. Corp. v. Williams, 905 F.2d 719, 723 (4th Cir. 1990) (holding that while the state law governing contract formation generally was valid under the FAA, a state could not circumvent the FAA "by enacting special rules to discourage or prohibit the formation of agreements to arbitrate").

Schlosser shows, however, that the Fourth Circuit has shifted its reasoning slightly. Rather than justifying the application of state law of contract formation under the "any contract" language of $\S 2$ of the FAA, the court in Schlosser found that general rules of contract formation are "a 'ground[] as exist[s] at law or in equity for the revocation of any contract,' within the meaning of 9 U.S.C. $\$ 2$." Schlosser, 980 F.2d at 259 (quoting 9 U.S.C. $\$ 2$ (1994)).

85. See Lee v. Chica, 983 F.2d 883, 885-86 (8th Cir. 1993) (distinguishing questions of contract formation governed by state law from other arbitration issues, but finding that this case did not involve a question of contract formation); Securities Indus. Ass'n v. 


\section{B. Arguing for the Application of State Contract Law Under the $F A A$}

The Fourth Circuit's reasoning-that state law of contract formation should govern determinations of whether an arbitration agreement has been formed-appears to be correct for several reasons. First, contract law is typically the domain of the states. ${ }^{86}$ The existence of a federal common law of contract was rejected in Erie, ${ }^{87}$ indeed, the very concept of a "federal contract law" is fairly amorphous. ${ }^{88}$ This is evident in Second Circuit opinions dealing with the FAA, which cite various cases from throughout the federal judiciary to support whatever proposition the court may be trying to prove at the moment. ${ }^{89}$ Further, these courts never define "federal contract law" nor attempt to justify its use. ${ }^{90}$

Second, courts cannot, consistently with the FAA, evaluate arbitration provisions differently from other contractual provisions. Evaluating arbitration agreements under federal law while evaluating all other contractual provisions under state law would place the arbitration provision on footing different from the rest of the contract; the arbitration provisions would receive preferential treatment. ${ }^{11}$ Such unequal footing, however, frustrates one very inipor-

Connolly, 883 F.2d 1114, 1120-21 (1st Cir. 1989) (using the same analysis as Lee).

86. See Aronson v. Quick Point Pencil Co., 440 U.S. 257, 262 (1979) (finding that state contract law could not be displaced, even when the contract related to intellectual property); see also Stewart Organization v. Ricoh Corp., 487 U.S. 22, 36 (1988) (Scalia, J., dissenting) ("Issues of contract . . . are nearly always governed by state law.").

87. See Erie R.R. Co. v. Tompkins, 304 U.S. 64, 78 (1938); see also Jack B. Weinstein, The Ghost of Process Past: The Fiftieth Anniversary of the Federal Rules of Civil Procedure and Erie, 54 BROOKLYN L. REv. 1, 20 (1988) ("Erie left to the states much of the necessary modem private law development in torts and contracts through case law and statutes and avoided the necessity of ad hoc decisions in this area by federal courts not particularly well qualified to develop private substantive law.").

88. Even the Restatement, although persuasive, is not "law that judges have a duty to uphold." STEVEN J. BuRTON \& MELVIN A. EISENBERg, CONTRACT LAW SELECTED SOURCE MATERIAL 3 (1996).

89. See, e.g., Genesco, Inc. v. T. Kakiuchi \& Co., 815 F.2d 840, 845-46 (2d Cir. 1987) (citing various Eighth and Eleventh circuit opinions to define federal law of contract formation).

90. See id; see also Mago v. Shearson Lehman Hutton, Inc., 956 F.2d 932, 934 (9th Cir. 1992). 1979).

91. See Supak \& Sons Mfg. Co. v. Pervel Indus., Inc., 593 F.2d 135, 137 (4th Cir. 
tant stated objective of the FAA- "to place [arbitration] agreements 'upon the same footing as other contracts." "'92

Third, and perhaps most important, circuits that apply federal law to discern if an arbitration agreement has been formed justify this application on a fundamental misreading of Supreme Court opinions. They confuse the issue of whether an arbitration clause has been formed with the issue of the scope of the arbitration agreement, that is, what issues the parties agreed to arbitrate. These courts cite the Supreme Court's opinions in Prima Paint, ${ }^{93}$ Moses Cone, ${ }^{94}$ and Mitsubishi Motors Corp. ${ }^{95}$ to support their application of federal law. However, these cases stand for the proposition that questions concerning whether a certain dispute is arbitrable under the terms of the arbitration agreement-the scope of the arbitration agreement-is a question of federal law. None of these opinions bear on the issue of how one should determine whether an arbitration provision has been formed.

This misreading of the Supreme Court's FAA opinions may explain wliy the Second Circuit lias contradicted itself on occasion, lolding that state law of contract formation governed formation questions. ${ }^{96}$ It may also explain why at least one district court judge within the Second Circuit lias considered the Circuit's arguments and explicitly rejected thein, choosing instead to apply state law to formation questions. ${ }^{97}$

92. Volt Info. Sciences, Inc. v. Board of Trustees of Leland Stanford Junior Univ., 489 U.S. 468, 474 (1989) (quoting Scherk v. Alberto-Culver Co., 417 U.S. 506, 511 (1974)).

93. See Genesco, 815 F.2d at 845 (citing Prima Paint Corp. v. Flood \& Conklin Mfg. Co., 388 U.S. 395, 404 (1967)).

94. See Neal v. Hardee's Food Sys. Inc., 918 F.2d 34, 37 n.5 (5th Cir. 1990) (citing Moses H. Cone Mem'l Hosp. v. Mercury Constr. Corp., 460 U.S. 1, $24-25$ (1983)).

95. Degaetano v. Smith Barney, Inc., 1996 U.S. Dist. LEXIS 1140, at *9-*10 (S.D.N.Y. 1996) (citing Mitsubishi Motors Corp. v. Soler Chrysler-Plymouth Inc., 473 U.S. 614, 626 (1985)).

96. See Progressive Cas. Ins. Co. v. C. A. Reaseguradora Nacional de Venezuela, 991 F.2d 42, 45 (2d Cir. 1993) ("Perry v. Thomas . . dictates that we apply state law in determining whether the parties have agreed to arbitrate." (citation omitted)). The Second Circuit has since tried to re-characterize the opinion in Progressive Casualty. In a subsequent case, the court characterized this opinion as standing for the proposition that "[w]ere our jurisdiction predicated upon diversity, there might be an argunent that we should defer to the New York courts when construing the choice of law/forum provision." In re Salomon, Inc., 68 F.3d 554, 559 (2d Cir. 1995) (citing Progressive Casualty, 991 F.2d at 46 n.6).

97. See Cook Chocolate Co. v. Salomon Inc., 684 F. Supp. 1177, 1181 (S.D.N.Y. 1988) (noting that, although the Second Circuit has held that federal law governs the 
The Supreme Court has in fact indicated that state law should govern formation and revocation questions. For example, in Perry v. Thomas, ${ }^{98}$ the Court noted in dictum that "state law, whether of legislative or judicial origin, is applicable [to resolving whether grounds exist for the revocation of a contract] if that law arose to govern issues concerning the validity, revocability, and enforceability of contracts generally." Court stated that $\S 2$ of the FAA established that "[s]tates may regulate contracts, including arbitration clauses, under general contract law principles." 101 And, even more recently, in Doctor's Associates $v$. Casarotto, ${ }^{102}$ the Court definitively stated that "the text of $\S 2$ [of the FAA] declares that state law may be applied" to determine questions of validity. ${ }^{103}$

The Court's most extensive examination of the role that state contract law should play occurred in First Options of Chicago, Inc. v. Kaplan. ${ }^{104}$ First Options involved a "workout agreement" embodied in four separate documents (for "working-out" debt) among First Options, the Kaplans, and the Kaplans' wholly owned investment company. ${ }^{105}$ When the Kaplans did not pay their debt to First Options, the company demanded arbitration pursuant to the workout agreement. ${ }^{106}$ However, the Kaplans had not personally signed the document containing the arbitration provision and denied that their dispute with First Options was arbitrable; the Kaplans also denied that an arbitrator could decide whetler the dispute was arbitrable. ${ }^{107}$ The Court found that the question of whether an arbitration provision was formed was really a question of contract formation that should be resolved by reference to state law. ${ }^{108}$ The relevant state law required the Court to "see whether

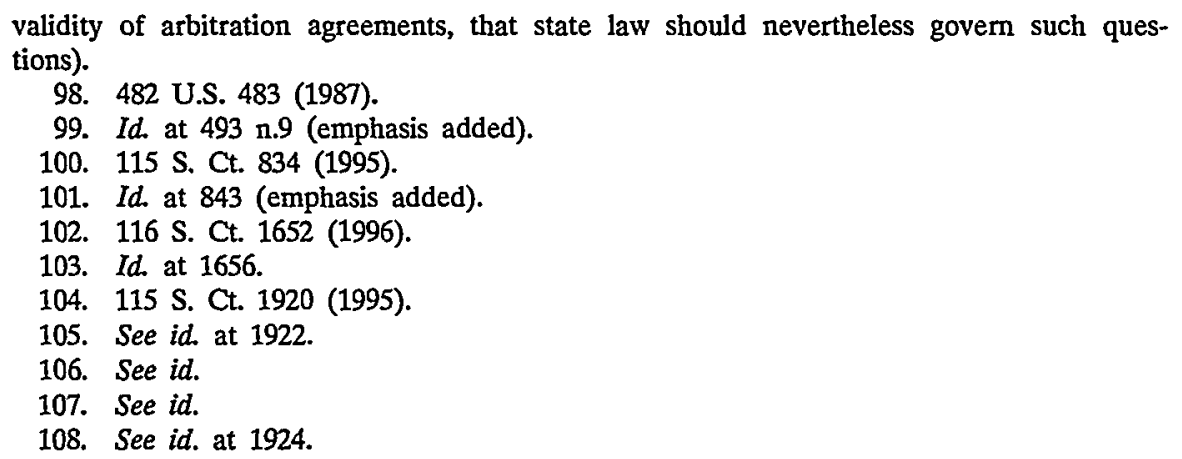


the parties objectively revealed an intent to submit the arbitrability issue to arbitration." 109

As a result of these unambiguous statements by the Supreme Court, courts should no longer disagree with the proposition that, under the FAA, state law should be applied to resolve certain limited questions. ${ }^{110}$ No doubt, state law which specifically restricts the enforceability of a valid arbitration agreement is still preempted by $\S 2$ of the FAA. ${ }^{111}$ However, an arbitration agreement must be valid for $\S 2$ to apply. ${ }^{112}$ State contract law governs this preliminary question-whether a given arbitration provision is valid, i.e., part of a contract. ${ }^{113}$ Thus, the FAA allows the use of state law to strike down arbitration agreements that would otherwise be enforced under the FAA. ${ }^{114}$

This result is consistent with the Supreme Court's statements. ${ }^{115}$ The Court has recognized that "[a] party may challenge $\ldots$ arbitration ... including the nonexistence of a valid arbitration agreement," based on "contract and arbitration law."116 Furthermore, "arbitration is ... a matter of contract between the parties." arbitrate a certain matter (including arbitrability), courts generally ... should apply ordinary state-law primciples that govern the formation of contracts."

109. Id. The Court then went on to consider the issue of who should decide the question of arbitrability. See id. at 1924-5.

110. Nevertheless, some federal courts are still holding that federal contract law should be applied to determine whether a valid arbitration agreement has been formed. See McPheeters v. McGinn, Smith \& Co., 953 F.2d 771, 772-73 (2d Cir. 1992); see also supra note 82.

111. See Doctor's Assocs., Inc. v. Casarotto, 116 S. Ct. 1652, 1655 (1996); Southland Corp. v. Keating, 465 U.S. 1, 16 (1984).

112. See Supak \& Sons Mfg. Co. v. Pervel Indus., Inc., 593 F.2d 135, 137 (4th Cir. 1979).

113. See Southland, 465 U.S. at 16 n.11 ("We agree, of course, that a party may assert general contract defenses such as fraud to avoid enforcement of an arbitration agreement.").

114. See Prima Paint Corp. v. Flood \& Conklin Mfg. Co., 388 U.S. 395, 403-04 (1967).

115. Cf. Pierce, supra note 23 , at $645-48$ (1992) (arguing that this is inconsistent with the purpose of the FAA).

116. DOMKE, supra note $25, \S 19.00$, at 275.

117. First Options of Chicago, Inc. v. Kaplan, 115 S. Ct. 1920, 1924 (1995).

118. Id. 


\section{Limits on the Application of State Contract Law}

Given that state law should govern whether a valid arbitration provision has been formed, the precise limits on a state's ability to govern formation questions must be defined. There must be some point at which state law is no longer a valid statement of contract formation but becomes an invalid undercutting of the FAA. Otherwise, states could simply pass laws prohibiting the "formation" of arbitration clauses, completely eviscerating the FAA.

Although the Supreme Court has reached this issue only recently, ${ }^{119}$ the touchstone seems to be the state law's level of generahity. In Doctor's Associates, Inc. v. Casarotto, ${ }^{120}$ the Court noted that any state law that "places arbitration agreements in a class apart from 'any contract,' and singularly limits their validity" is preempted by federal law. ${ }^{121}$ Also, in Perry $v$. Thomas, ${ }^{122}$ the Court noted in dictum that

state law ... is applicable if that law arose to govern issues concerning the validity, revocability, and enforceability of contracts generally. A state-law principle that takes its meaning precisely from the fact that a contract to arbitrate is at issue does not comport witl this requirement of $\S 2 . .^{123}$

Thus, any law governing an arbitration provision inust apply equally to all other provisions of any contract. ${ }^{124}$ The state law must also provide a ground for rejecting the contract, not merely an arbitration provision. ${ }^{125}$ Finally, and most important, the state law cannot undercut the FAA. ${ }^{26}$

119. See Doctor's Assocs., Inc. v. Casarotto, 116 S. Ct. 1652, 1655-56 (1996). Prior to its decision in Casarotto, the Supreme Court addressed this issue only sparingly in footnotes. See Southland Corp. v. Keating, 465 U.S. 1, $16 \mathrm{n.11}$ (1984). The most complete analysis of whether a given state law of contract formation is valid under the FAA was Justice Stevens' dissent in Southland. See id. at 17-21 (Stevens, J., concurring in part and dissenting in part). However, the Court rejected his reasoning, fearing that "states could wholly eviscerate congressional intent to place arbitration agreements 'upon the same footing as other contracts." Id. at $16 \mathrm{n} .11$ (quoting H. R. REP. No. 96-68, supra note 30 , at 1 .

120. 116 S. Ct. 1652 (1996).

121. Id. at $1656-57$.

122. 482 U.S. 483 (1987).

123. Id. at 493 n.9 (emphasis added).

124. See id. at $492-93$ n.9.

125. See Southland, 465 U.S. at 16 n.11.

126. See Satum Distrib. Corp. v. Williams, 905 F.2d 719, 726 (4th Cir. 1990). 
Lower courts applying state law of contract formation have rendered decisions that demonstrate how difficult it is to distinguish between a valid application of the law of contract formation and an invalid undercutting of the FAA. For example, in one of the earliest cases discerning this difference, Supak \& Sons Manufacturing Co. v. Pervel Industries, Inc. ${ }^{127}$ the Fourth Circuit struck down an arbitration provision contained in a sales confirmation form. ${ }^{128}$ Under the relevant state law, since the arbitration agreement was "a per se material alteration of the contract," 129 it was not part of the original contract negotiations but was instead an additional term. ${ }^{130}$ The court considered and rejected the idea that "holding an arbitration clause to be a per se material alteration" was contrary to the FAA. ${ }^{131}$ Instead, the court found that the state law governing inaterial alterations was a general rule of contract formation permissible under the FAA. ${ }^{132}$

In subsequent cases, liowever, the Fourth Circuit lias not been able to persuasively inaintain a distinction between permissible and impermissible uses of state contract law. For example, it struck down a Virginia statute that prohibited "automobile manufacturers and dealers from entering into agreements that contain[ed] mandatory alternative dispute resolution provisions." ${ }^{\text {233 }}$ The court ruled that the validity of the Virginia statute depended on whether it was "an unremarkable part of Virginia's general laws of contract formation" ratlrer than an "idiosyncratic rule specific to arbitration agreements." 134 In this case, Virginia did not generally "bar parties from making certain provisions of their contracts nonnegotiable." 135 Thus, the statute was an invalid singling out of arbitration agreements. ${ }^{136}$ Two years later, however, the Fourth Circuit held unenforceable an arbitration agreement between a public

127. 593 F.2d 135 (4th Cir. 1979).

128. See id. at 137.

129. Id. at 136 (citing Frances Hosiery Mills, Inc. v. Burlington Indus., Inc., 204 S.E.2d 834, $841-42$ (N.C. 1974); Marlene Indus. Corp. v. Carnac Textiles, Inc., 380 N.E.2d 239, 242 (N.Y. 1978)).

130. See Supak \& Sons Mfg. Co. v. Pervel Indus., 593 F.2d 135, 136 (4th Cir. 1979).

131. Id. at 137.

132. See id.

133. Satum Distrib. Corp. v. Williams, 905 F.2d 719, 721 (4th Cir. 1990) (reviewing

VA. CODE ANN. § 46.1-550.5:27 (Michie 1989 Supp.)).

134. Id. at 725 .

135. Id. at 726 .

136. See id. 
school board and a construction company as ultra vires. ${ }^{137}$ The Virginia legislature had granted all powers of contract to the school board except the power to agree to arbitrate. ${ }^{138}$ The court held that this did not run afoul of the FAA because laws defining ultra vires acts are generally applicable. ${ }^{139}$

As these Fourth Circuit cases illustrate, it is difficult to determine when state laws of contract formation can invalidate arbitration clauses under the FAA. However, the Supreme Court's announcements regarding the validity of state arbitration law indicate that the Fourth Circuit's generality test may be a starting point for defining proper state laws of contract formation. Utilizing this test to evaluate the validity of such laws is consistent with the FAA and gives states an active voice in arbitration law. Allowing the states this voice may quell the tension between state and federal courts illustrated by Justice Trieweiler's special concurrence in Casarotto v. Lombardi ${ }^{140}$ and by Casarotto's subsequent treatment by the Supreme Court. ${ }^{141}$

\section{CASAROTTO}

In Casarotto $v$. Lombardi, ${ }^{142}$ the Montana Supreme Court expressed its concern that the FAA's preemptive effect would invalidate statutes designed to protect Montanans from oppressive contractual provisions. ${ }^{143}$ However, both the state Supreme Court and the U.S. Supreme Court did not consider neutral Montana statutes governing contract formation that could have been used to invalidate the arbitration provision at issue in Casarotto.

The Casarotto case involved a dispute between parties to a franchise agreement for the operation of a Subway sandwich franchise in Great Falls, Montana. After the plaintiffs, the franchisees, were denied a promised prime location for their store, they filed suit for breach of contract in a Montana state court. ${ }^{144}$ The defendant, Doctor's Associates, Inc., and its agent, Nick Lombardi,

\footnotetext{
137. See W. M. Schlosser Co. v. School Bd., 980 F.2d 253, 258 (4th Cir. 1992).

138. See id. at $256-57$.

139. See id. at 259.

140. 886 P.2d 931, 939-41 (Mont. 1994) (Trieweiler, J., specially concurring).

141. 901 P.2d 596 (Mont. 1995), rev'd, 116 S. Ct. 1652 (1996).

142. 886 P.2d 931 (Mont. 1994), vacated and remanded, 115 S. Ct. 2552 (1995); reaffd, reinstated 901 P.2d 596 (Mont. 1995), rev'd, 116 S. Ct. 1652 (1996).

143. See Casarotto, 886 P.2d at 939-41 [hereinafter Casarotto I].

144. See id.
} 
moved to have the suit stayed pending the resolution of arbitration pursuant to an arbitration clause in the parties' franchise agreement. ${ }^{145}$ The Montana District Court granted this motion.

The Supreme Court of Montana reversed on the ground that the arbitration provision was not enforceable. ${ }^{146}$ Montana law requires all contracts that include arbitration provisions to note on the first page of the contract, in underlined, capital letters, the inclusion of an arbitration clause. ${ }^{147}$ The Casarottos' contract had no such notation on the first page; thus, under Montana law, the Casarottos had received insufficient notice of the arbitration clause. ${ }^{148}$ The Casarotto court identified the inotivation for this notice requirement: "[T] he legislative committee ... did not want Montanans to waive their constitutional right of access to Montana's courts unknowingly, and ... they were concerned about Montanans being compelled to arbitrate disputes at distant locations beyond the [state's] borders." 149

The court further held that Montana's notice requirement was not preeinpted by the FAA. ${ }^{150}$ The court explained that the notice requirement did "not undermine the policies of the FAA" and "that the FAA [did] not require parties to arbitrate when they [liad] not agreed to do so."151 Further, the Umited States Supreme Court could not "find it a threat to the policies of the Federal Arbitration Act for a state to require tlrat before arbitration agreeinents are enforceable, they be entered knowingly. To hold otherwise would be to infer that arbitration is so onerous . . . that it can only be foisted upon the uninformed."152

In a special concurrence, Justice Trieweiler stated the court's position more forcefully. ${ }^{153} \mathrm{He}$ argued that Montana had a "sophisticated system of justice"154 made of statutes and rules that

\footnotetext{
145. See id.

146. See id. at 939.

147. See MONT. CODE ANN. \& 27-5-114(4) (1995). This statute provides:

Notice that a contract is subject to arbitration pursuant to this chapter shall be typed in underlined capital letters on the first page of the contract; and unless such notice is displayed thereon, the contract may not be subject to arbitration.
} Id.

148. See Casarotto I, $886 \mathrm{P.2d}$ at 933.

149. Id. at 935 .

150. See id. at 938-39.

151. Id. at $938-39$.

152. Id. at 939 .

153. See id. at 939-41 (Trieweiler, J., specially concurring).

154. Id. at 939. 
protects Montanans from "bad faith, fraud, unfair busmess practices, and oppression."155 All of these carefully crafted rules, however, were being undermined by the FAA. ${ }^{156}$ In Justice Trieweiler's words

due to [the federal judiciary's] misinterpretation of congressional intent when it enacted the Federal Arbitration Act, and due to their naive assumption that arbitration provisions and choice of law provisions are knowingly bargained for, all of these procedural safeguards and substantive laws are easily avoided by any party with enough leverage to stick a choice of law and an arbitration provision in its pre-printed contract and require the party with inferior bargaining power to sign it. ${ }^{157}$

On appeal, the Supreme Court summarily vacated the Montana Supreme Court's opinion and remanded the case to Montana's highest court for consideration in light of its decision in Dobson, ${ }^{158}$ which considered whether the "involving commerce" language used in $\S 2$ of the FAA provided a limit on the scope of the Act. ${ }^{159}$

On remand, the Montana Supreme Court reaffirmed its previous decision. ${ }^{160}$ The Court began its analysis by reiterating its first opinion. It found that the goals and policies of the FAA were not undermined by Montana's notice requirement ${ }^{161}$ and that the "Supreme Court would not find it a threat to the policies of the Federal Arbitration Act for a state to require that before arbitration agreements are enforceable, they be entered knowingly." 162 The court then examined these findings in light of Dobson. It summarized the holding in Dobson as giving the FAA preemptive effect over all "transactions which, in fact, involve interstate coinmerce, even though a counection to interstate commerce inay not have been contemplated by the parties."163 The court then concluded that "nothing in the Dobson decision ... relates to the

155. Id.

156. See id. at 940.

157. Id.

158. 115 S. Ct. 2552 (1995).

159. See supra notes $65-71$ and accompanying text.

160. See Casarotto v. Lombardi, 901 P.2d 596 (Mont. 1995) [heremafter Casarotto II].

161. See id. at 597.

162. Id. at 597-98 (quoting Casarotto I, 886 P.2d at 938-39).

163. Id. at 598 . 
issues presented to this Court in this case"164 and upheld its previous decision.

On subsequent appeal, the Supreme Court restated its disagreement with the Montana court's approach, reversing the court's decision eight-to-one. ${ }^{165}$ In a very brief opinion, Justice Ginsburg held that Montana's notice requirement was inconsistent with the FAA. ${ }^{166}$ She explained that the goals of the FAA were "antithetical to threshold limitations placed specifically and solely on arbitration provisions." 167 Further, the Montana notice requirement singled out arbitration clauses and was therefore invalid. ${ }^{168}$ Justice Ginsburg did not address Justice Trieweiler's special concurrence or his concerns for the citizens of Montana.

On remand (for the second time), the Montana Supreme Court's defiance of the U.S. Supreme Court continued. Rather than follow the Supreme Court's order to remand the Casarotto case for further proceedings consistent with the Supreme Court's opinion, Justices Trieweiler and Hunt refused to sign a remand order. ${ }^{169}$ Justice Trieweiler reasoned:

We cannot in good conscience be an instrument of a policy which is as legally unfounded, socially detrimental and philosophically nnisguided as the U.S. Supreme Court's decision in this and other cases which interpret and apply the Federal Arbitration Act. ${ }^{170}$

Although this protest will have no formal effect on subsequent proceedings, it symbolizes the great frustration that some state judges feel over the broad preemptive effect of the FAA.

\section{REVISITING CASAROTTO IN THE LIGHT OF STATE LAW OF CONTRACT FORMATION}

The series of state and federal opinions in Casarotto $v$. Lombardi illustrates not only the tension between state and federal courts over the role of state arbitration law, but also how state

164. Id.

165. See Doctor's Assocs., Inc. v. Casarotto, 116 S. Ct. 1652, 1654, 1655-57 (1996).

Justice Thomas was the sole dissenter in Casarotto.

166. Id. at 1657 .

167. Id.

168. See id.

169. See Reuben, supra note 21 , at 16 .

170. Id. 
law of contract formation can relieve this tension. The concerns of Justice Trieweiler could have been addressed without this contentious and lengthy litigation. Justice Trieweiler's actions were motivated by his concern that Montana's carefully crafted system of protection for its citizens was being eviscerated by the FAA. ${ }^{171}$ Witlout safeguards such as a notice requirement, he said, you get "a bunch of out-of-state corporations imposing arbitration on local residents through clauses buried in contracts of adhesion." ${ }^{\text {"172 }}$ The true gist of his concern is a fear that unconscionable and adhesive contracts could be foisted on Montanans.

This fear can be addressed in a manner consistent with the FAA by using state law of contract formation to strike down troubling arbitration provisions. In fact, Montana has in place statutes and common law relating to unconscionability that might invalidate the arbitration provision at issue in Casarotto and protect all Montanans from oppressive arbitration provisions in a manner consistent with the FAA.

Montana courts have held that arbitration provisions, like all other contractual provisions, are subject to the state's laws governing unconscionability. ${ }^{173}$ Pursuant to Montana's common law, arbitration agreements are enforceable even if they appear in contracts of adhesion, unless there is evidence that the agreement is "oppressive or unconscionable." 174 A contractual provision (or an entire contract) is unconscionable and invalid under Montana law if 1) "the contractual terms are unreasonably favorable to the drafter" and 2) "there is no meaningful choice on the part of the other party regarding acceptance of the provisions." 175 To determine whether a particular contract is unconscionable, the courts also examine factors such as unequal bargaining power, lack of meaningful choice, oppression, and exploitation of the weaker

171. See supra note $153-57$ and accompanying text.

172. Reuben, supra note 21 , at 16 (quoting Trieweiler, J.).

173. Chor v. Piper, Jaffray \& Hopwood, Inc., 862 P.2d 26, 30 (Mont. 1993) (finding that the arbitration provision at issue was not unconscionable); Passage v. PrudentialBache Sec., Inc., 727 P.2d 1298, 1302 (Mont. 1986).

174. Chor, 862 P.2d at 30.

175. Leibrand v. National Farmers Union Property \& Cas. Co., 898 P.2d 1220, 1227 (Mont. 1995). These two elements are also reformulated as "oppression and disparity of bargaining power." In re Estate of Russel Michael, Jr., 871 P.2d 272, 275 (Mont. 1994). 
party's vulnerability or lack of sophistication. ${ }^{176}$ Ultimately, unconscionability is a question of law. ${ }^{177}$

There are not enough facts in the Casarotto opinions to determine whether the particular arbitration provision in question was unconscionable. However, Montana's general principles of unconscionability are written such that their apphication in Casarotto would not have been exceptional. After all, the Casarottos appear to have been a weak and vulnerable party; they were forced to open their Subway shop in a less-than-desirable location and were ignored when prime locations for their store became available. ${ }^{178}$ These facts could indicate that the Casarottos were also forced into an unconscionable arbitration clause.

Clauses that are unconscionable should be struck from a contract. Under the Uniform Commercial Code and the Second Restatement of Contracts, courts can either refuse to enforce unconscionable contracts or strike out specific clauses that are unconscionable. ${ }^{179}$ Montana law is consistent: if provisions of a contract are found unconscionable, Montana courts have the option of invalidating the entire contract, or the unconscionable provisions. ${ }^{180}$

Striking down an arbitration provision on grounds of unconscionability should be allowed under the FAA. The Supreine Court requires courts to treat arbitration provisions like all other contractual provisions. ${ }^{181}$ Thus, if all other contractual provisions are subject to unconscionability laws, arbitration provisions should also be subject to these laws. Otherwise, one of the fundamental tenets of the FAA-that arbitration provisions should exist "upon the same footing" as all other contractual provisions ${ }^{182}$-would be violated.

176. See Kelly v. Widner, 771 P.2d 142, 145 (Mont. 1989).

177. See id.

178. See Casarotto I, 886 P.2d 931, 932-33 (Mont. 1994).

179. See U.C.C. § 2-302(1) (1995); RESTATEMENT SECOND OF CONTRACTS § 208 (1981).

180. See MONT. CODE ANN. \& 30-2-302 (1995). This section provides:

If the court as a matter of law finds the contract or any clause of the contract to have been unconscionable at the time it was made the court may refuse to enforce the contract, or it may enforce the remainder of the contract without the unconscionable clause.

Id. (emphasis added). See also Kelly, 771 P.2d at 144-45 (applying this provision).

181. See Volt Info. Sciences, Inc. v. Board of Trustees of Leland Stanford Junior Univ., 489 U.S. 468, 474 (1989).

182. See supra note 92 and acconpanying text. 
Nevertheless, the Supreme Court has indicated in dictum that state unconscionability laws must invalidate the whole contract, not just the arbitration clause, in order to be a valid exercise of state contract formation law under the FAA. ${ }^{183}$ This dictum is antithetical to the FAA and to general principles underlying unconscionability. First, as noted above, requiring courts to invalidate an entire contract if only a single arbitration provision is unconscionable would limit the court's options with respect to the arbitration provision, thus placing arbitration clauses on grounds that differ from other contractual provisions. ${ }^{184}$

Second, requiring courts to invalidate an entire contract is contrary to unconscionability principles. Unconscionability is an equitable principle. ${ }^{185}$ Historically, courts in equity could not rescind contracts based on unconscionability, ${ }^{186}$ they could only stay the hand of those attempting to enforce such contracts. ${ }^{187}$ Modern remedies for unconscionability reflect these equitable principles. Underlying modern remedies is the notion "that a court inay withhold relief just as it miglit refuse specific performance, not that a party may avoid the contract as he might for misrepresentation or duress." 188 Further, courts usually refuse to enforce particular clauses that are unconscionable and fashion remedies to save the rest of the contract. ${ }^{189}$ To deny courts this usual remedy when an arbitration clause is at issue would ignore the origin of the unconscionability doctrine and the nnodern law of remedies for unconscionable contracts.

Other state law grounds, in addition to unconscionability, may exist for invalidating the arbitration provision at issue in Casarotto. Under Montana common law, contractual provisions that limit a party's access to a Montana court are void. This general principle was announced by the Montana Supreme Court in an 1899 opinion, Wortman v. Montana Central Railway Co. ${ }^{190}$ In Wortman, the court argued "that parties cannot stipulate beforehand to sub-

183. See Southland Corp. v. Keating, 465 U.S. 1, 16 n.11 (1984).

184. See supra notes $92,174-77$ and accoinpanying text.

185. See E. ALLAN FARNSWORTH, CONTRACTS 302 (1982).

186. See id. at 306 n.16.

187. See id.

188. Id. at 309.

189. See id:; See also Ashland Oil, Inc. v. Donahue, 223 S.E.2d 433 (W. Va. 1976) (formulating such a remedy).

190. 56 P. $316,320-21$ (Mont. 1899). 
mit their rights generally to the judgment of a designated third person for final determination. The effect of such a stipulation is ... to restrict parties from enforcing their rights under the contract by the usual legal proceedings in the ordinary tribunals. ${ }^{" 191}$ This principle was later codified. ${ }^{192}$

A legitimate purpose underlies the Wortman decision and the Montana statute that codified this decision: to invalidate forumselection clauses. ${ }^{193}$ The Montana courts and legislature have developed a public policy that disallows forum-selection clauses. This policy furthers the Montana Constitution's statement that speedy remedies must be afforded every person; forum-selection clauses "impede the right to judicial process and especially discourage a speedy remedy."194

This forum selection policy could have been used to invalidate the arbitration provision at issue in Casarotto. The arbitration provision in the Casarottos' franchise agreement required that the arbitration take place in Connecticut. ${ }^{195}$ Thus, the arbitration provision served as a forum-selection clause that restrained the plaintiffs' access to the Montana courts. ${ }^{196}$ Invalidating the arbitration provision would be consistent with Southland because the forum-selection statute is a general rule, applicable to all contracts and contractual provisions that have their basis in Montana com-

191. Id.

192. See MONT. CODE ANN. $\$ 28-2-708$ (1995). This provision reads as follows: Restraints upon legal proceedings void. Every stipulation or condition in a contract by which any party thereto is restricted from enforcing his rights under the contract by the usual proceedings in the ordinary tribunals or which limits the time within which he may thus enforce his rights is void. This section does not affect the validity of an agreement enforceable under Title 27, chapter 5 [Montana's Uniform Arbitration Act].

Id. See also Polaris Indus., Inc. v. District Court of the Thirteenth Judicial District, 695 P.2d 471, 472 (Mont. 1985) (considering this statute).

193. Polaris, 695 P.2d at 473 (Sheehy, J., concurring).

194. Id. at 472 (Sheehy, J., concurring).

195. See Casarotto II, 901 P.2d 596, 597 (Mont. 1995).

196. See, e.g., Smith v. Zepp, 567 P.2d 923 (Mont. 1977) (decided prior to the time when the arbitration exception was included in the Montana code and holding that such arbitration provisions would be invalid). 
mon law. ${ }^{197}$ As such, it is "grounds as exist at law or in equity for the revocation of any contract." 198

The forum-selection statute could be used in another way to uphold Montana's notice requirement. There is one exception to this statute's prohibition on forum-selection: all contractual provisions formed pursuant to Montana's Uniform Arbitration Act ${ }^{199}$ are valid and enforceable. ${ }^{200}$ The Montana forum-selection statute excepts all arbitration provisions that meet the general requirements of Montana's Uniform Arbitration Act. ${ }^{201}$ In other words, Montana's Act defines a system of arbitration that might otherwise be invalid under the general forum-selection provision. Although parties are funnelled into Montana's system of arbitration, in general, arbitration is advanced because it is preserved. When the whole system of Montana's laws are considered, the notice requirement defined in Montana's Uniform Arbitration Act is pro-arbitration-it makes possible an arbitration agreement that would otherwise be invahid under general Montana law.

In sum, Montana's law of contract formation could have been used to invalidate the arbitration clause at issue in Casarotto: the clause appears to be unconscionable and violative of the state's forum selection laws. Had the Montana Supreme Court in Casarotto applied the state's contract law rather than the state's arbitration law, it could have struck down the arbitration clause, eased its concerns over adhesive contracts, and avoided the preemptive reach of the FAA.

\section{CONCLUSION}

The broad scope of the FAA, combined with the U.S. Supreme Court's interpretation of its preemptive effect, has severely restricted the ability of states to regulate arbitration agreements. Although parties may individually "opt out" of the FAA, states are denied an active voice in arbitration law. As illustrated by

197. See 9 U.S.C. \& 2 (1994) (stating that such provisions could be rejected upon grounds applicable to all contract provisions); see also supra notes $110-18$ and accompanying text (arguing that the application of state law to this question is valid under Southland).

198. 9 U.S.C. \& 2 (1994).

199. See MONT. CODE ANN. $\S 27$ ch. 5. (1995).

200. See id. \& 28-2-708 (1995).

201. See id. 
Casarotto $v$. Lombardi, this denial increasingly frustrates state courts and legislatures that wish to protect their citizens fron1 arbitration provisions.

This Note has argued that such frustration can be relieved if state courts and legislatures refocus on contract formation. The use of state contract law to determine whether a valid arbitration agreement has been reaclied could provide state legislatures and courts with a way to address their concerns about arbitration agreements while avoiding the preemptive effect of the FAA. 